\title{
Emphasizing Fish, Fisher, and Sea for the Mission of Christian Churches in the Context of the Marine Ecological Crisis: A Response to the Ten Commandments of Food
}

\author{
Elia Maggang | ORCID: 0000-0001-7551-8216 \\ PhD Student, Lincoln Theological Institute, University of Manchester, \\ Manchester, UK \\ elia.maggang@postgrad.manchester.ac.uk
}

\begin{abstract}
This article offers a theological response to the Ten Commandments of Food (TCF) in the context of the marine ecological crisis. The TCF is a unique and effective campaign for food security which advocates for sustainable living through the mission of Christian churches. As the campaign includes farmers, it reframes food security and sustainability as a part of ecclesial life. However, the neglect of fish, fisher, and sea in the TCF has negative consequences for marine ecosystem. This exclusion endangers the sustainability of marine life and all those who depend on the sea for livelihood and sustenance. Therefore, this article suggests that it is essential to include fish, fisher, and sea in the TCF - noting that they have a crucial place in Christianity as depicted particularly in the ministry of Jesus and his disciples. This will make the TCF a more comprehensive campaign with positive contributions for marine life.
\end{abstract}

\section{Keywords}

Ten Commandments of Food - fish - fisher - sea - church mission - marine ecological crisis 
In 2016 the World Council of Churches (WCC) published the Ten Commandments of Food (TCF) proposed by the wCC general secretary Rev. Dr Olav Fykse Tveit. The TCF is a form of the Food for Life Campaign that assists congregations to challenge hunger and inequity, and other issues related to food security (WCC 2016:3). Generally speaking, this campaign addresses three subjects: food, the people who provide and produce food, and the mediums from which food comes (see Figure 1). It offers certain attitudes concerning those subjects in order to ensure that all people have enough nutritious food. Undoubtedly, it is essential for Christian voices to speak out against the practices that lead to hunger, inequity and malnutrition. It is also crucial to support any effort that addresses those issues, especially in local congregations. In this regard, the TCF is significant in building popular awareness of these issues, especially among Christians, because it can reach the grassroots with formulations which are simple to comprehend and proclaim. An essential result of this campaign is that it leads to practical responses. With simple and clear words, the TCF encourages Christians to have Christian attitudes toward food, those who provide the food, and the environments where food comes from. These all show the fundamental role of the TCF in the daily life of Christian congregations with the potential to have a huge positive impact on the wider environment.

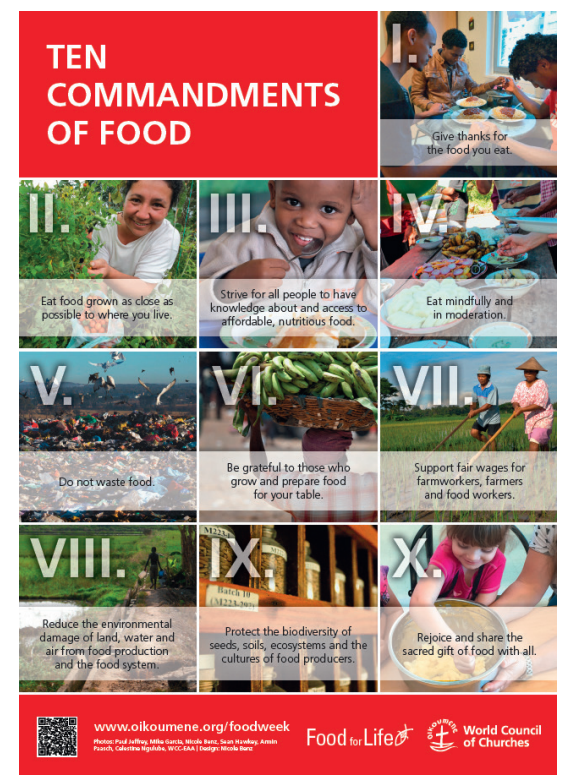

FIGURE 1

The poster campaign of the Ten Commandments of Food 
However, as portrayed in figure 1 , the TCF neglects the existence of the sea ${ }^{1}$ as a source of food for the world population and the main source of food and nutrition for the congregations whose life depends on the sea. This neglect can be seen in the background picture and formulation of each commandment: no fish caught but food grown, no fisher but farmer, no sea but soils. The guidelines of the campaign mention fish as an important food and artisan fisher folk as having essential roles, but their omission from the commandments themselves implies a preference for farming over dependence on the sea. There is a biblical verse related to the sea which is Genesis 1:26 and a reference to exploitation at sea (WCC 2016:16, 19). However, I suggest that fish, fisher and sea are not included in the formulations of the TCF, although I believe that the neglect is unintentional.

That unintentional neglect should not happen when the world today faces marine ecological crisis (pollution, illegal fishing, destructive fishing practices, and the exploitation of sea resources, fisher and seafood workers) and their impacts on food security. The abandonment of theological concern with the sea will have negative impacts on ecclesial life as well as the marine environment, which are certainly contradictive to what is expected from the TCF. Therefore, I am suggesting in this article that it is essential to focus on the sea in the TCF, including its roles as a source of life, food, and livelihood. The inclusion of fish, fisher and, sea will make the TCF a more comprehensive campaign. It will enhance the contribution of the mission of Christian churches in the context of the marine ecological crisis. The suggestion will start with an elaboration of my claim that the TCF neglects fish, fisher and sea, followed by discussions on the implications of the TCF in ecclesial life and environmental crisis.

In addition, as this article deals with food for humans, I need to clarify that my perspective is not anthropocentric both ontologically and ethically (See Dzwonkowska 2018:724-6). Each of God's creatures has its own intrinsic value in the interconnected and interdependent community of creation (Johnson 2014:119; Bauckham 2016:64). It is clear that some creatures are consumed by humans, yet they do not exist merely as food for humans. In fact, humans also become food for some other creatures in the food chain. When human beings eat, they also feed other living creatures in their body. Therefore, I agree with Ernst M. Conradie who claims that humans and some other creatures relate to one another that way - to eat and be eaten - in the interest of allowing life to flourish (2018:77). It is in this way of thinking I address the TCF which specifically speaks of food for humans.

1 The sea in my usage in this article includes ocean. 
The formulation, background pictures and guidance of each commandment in TCF consistently ignores the sea. I will show this by focusing on three words: fish, fisher and sea. Firstly, the abandonment of fish is depicted clearly in the second commandment which says, "Eat food grown as close as possible to where you live." It is not difficult to identify my claim in this formulation. The "food grown" certainly does not refer to fish but to agricultural plants. One could argue that it points to seaweed or other products of aquaculture. However, despite the high production of "capture" fisheries, which is 81.2 million tons in 2015 and 79.3 million tons in 2016 (FAO 2018:4), the guidance of this commandment and the rest related to this subject does not indicate that the "food grown" also includes aquaculture. This can be seen clearly in the guided discussion on this commandment according to the prophecy of Micah 4:3-4 and Isaiah 4:4 about the establishment of God's reign in the future. It is said in the guidance that in the day to come "nations will invest in development and in agriculture." Accordingly, the guidance implies that this second commandment encourages Christians to eat that kind of food because, despite the issue of freshness, nutrition and taste, it supports local farm families, local varieties, and so on. In doing so, the guidance says, "we contribute to preserving the agricultural landscape" (wCC 2016:6). It is clear, then, that the food mentioned in this commandment is not envisaged to include fish or other kinds of food from the sea or fresh water.

Secondly, fishers are ignored in the seventh commandment commanding Christians to "Support fair wages for farmworkers, farmers and food workers." With references to Amos' prophetic words in Amos 8:4-6; 5:24 and James' resistant words in James $5: 1-4$, the main idea of this commandment is to seek justice for those, especially the poor and the weak, who work to provide food. The seventh commandment resists any kind of exploitation over these people. Unfortunately, this formulation in the second commandment excludes fishers from that support. This is at odds with the guidance of this commandment which recognizes that fishers have been exploited (WCC 2016:15-16). This raises a very important question, why has this commandment not put fishers in its formulation? One might argue that fishers are included in the group of food workers or farm workers. However, although there are fish farms in many places, these are different from the industry of fishing. In fact, why are farmers not included in the group of food workers but are considered as a different group? This question simply affirms that fishers are ignored in this commandment. 
Lastly, the sea is neglected specifically in the eighth and ninth commandments that speak of the medium from which food comes. In the eighth commandment, the TCF encourages Christians to "Reduce the environmental damage of land, water and air from food production and food system." It could be argued that the sea is not abandoned here because the water in this commandment includes the sea. The guidance could be referred to as a support as it does mention marine areas along with freshwater contaminated because of the industrial-scale commercial farming (wCC 2016:17-18). However, it is not enough to mention water and then expect people to discern that the commandments fully apply to sea, given that fish and fishers have not been included in previous commandments. In fact, although the guidance mentions marine areas, the actions offered in this commandment do not suggest the sea has been considered. The actions are addressed to land-based farming (WCC 2018:18). It is clear that pollution, for instance, in this area will affect the sea. However, the sea pollution issue is wider than that and requires specific efforts. In addition, the reference to Jeremiah 12:4 speaks only of the land and injustice; injustice occurring in or about the sea is ignored.

The neglect of the sea is depicted more clearly in the formulation of the ninth commandment. It says, "Protect the biodiversity of seeds, soils, ecosystems and the cultures of food producers." With references primarily to Genesis 1:11, 20, 24, 28 and 9:8-11, this commandment focuses on the sustainability of biodiversity for (non-human) living creatures. It speaks of all crucial things that support that sustainability, namely seeds, the environments and mediums in which the creatures live, and human's role. The guidance mentions the significance of fish in the world's food stock and the problem of declining fish species. It also acknowledges the capacity of artisanal fisher folk to deal with that issue. Nevertheless, the guidance does not name the sea as a marine ecosystem that needs to be protected. Nor is there any action proposed to protect the sea (wCC 2016:17) as if the sea is too big to be adversely affected by humans or not vulnerable like the land. It is not surprising, then, that the formulation of this commandment mentions soils that point to the land and agriculture, but does not mention sea or marine areas.

Hence fish, fishers, and sea are neglected in the TCF although their existences are acknowledged in the guidelines as crucial for food security. The formulations of the TCF consistently exclude the fish, fishers and sea. The guidance of the TCF gives attention to those three but neglects them at the end. There is no explicit command regarding the eating of fish; or in support and advocacy towards fishers; and none to look after the sea.

That, certainly, has implications for the campaign itself and for the Christian churches in WCC in regard to their public engagement. I will identify and 
discuss such consequences in the following sections. Although the neglect of fish, fisher and sea leads to negative implications, they are not my main concern. My purpose is to offer theological insights in order to strengthen this campaign. Therefore, in the following two sections I will explore the positive implication of the TCF and then demonstrate the negative consequence of neglecting the sea. This leads to a final section which discusses fish, fisher, and sea in the mission of Christian churches in relation to the marine ecological crisis. In this endeavour, the Protestant Evangelical Church in Timor (GMIT), a member of WCC, will be the specific context to see how the TCF works because GMIT's congregations situate in inland and coastal areas. ${ }^{2}$

\section{The Implication of the TCF for Ecclesial Life}

Undoubtedly, the TCF is an innovative campaign that has positive impacts in various forms in the life of Christian congregations. In the context of the global challenges regarding food security, the TCF can be seen as a prophetic voice that affirms the engagement, effort and position of wCC in this problem. It is a crucial step forward. The WCC has challenged diverse kinds of injustice surrounding food security issues. This, certainly, becomes an ecclesial justification that stimulates, encourages and supports any effort in congregational contexts to work on food security issues. That legitimacy applies to pastors, especially those who seek to develop economic empowerment through farming activities in their congregations. It also applies to the members who work as farmers and other professionals that support the farmers. That justification has positive implications for the mission of the Christian churches.

For the pastors, the TCF gives value and encouragement to their efforts. That is essential particularly in the church's ministry in rural areas. An ongoing form of ministry at GMIT is a case in point. In 2016, several pastors of GMIT formed a group they called Kompastani (the community of pastors who like farming), to empower the local farmers to cultivate their farms with better

2 GMIT has become a member of WCC since 1948, and most of GMIT's territory of ministry locates in the East Nusa Tenggara Province (NTT) of Indonesia (World Council of Churches n.d.). As the sea encompasses about two-third of NTT territory, the sea is essential alongside the land for food and livelihood of the province inhabitants (See Fitriana and Stacey 2012), including the members of GMIT. The waters of NTT such as the Savu Sea is part of the coral triangle which is significant not only for NTT but also the whole world (White 2014:92; Burke et al. 2012:7-10). 
farming practices. ${ }^{3}$ This transformative diakonia is crucial because of geographic conditions including water issues, along with the lack of adequate skills, information, support, motivation and human resources in rural areas. As a result, farmers do not fully benefit from their land to fulfil their life necessities, particularly for nutritious food. In various ways Kompastani has assisted local farmers in rural areas to cultivate their land and benefit from it. Indeed, Kompastani specifically applies the seventh commandment of the TCF.

At this point, the TCF justifies and strengthens church mission in food security. Mission is not only about food for the soul but also for the body (Niyonsaba 2018). Church ministry when understood as transformative diakonia should also be addressed toward table service in various forms to make sure that all people always have enough food. Acts 6:1-7 speaks of the significance of table service. Jesus in his ministry was always concerned with people's welfare. Having enough food to eat is in his teaching of prayer (The Lord's Prayer), and it appears consistently in his ministry, including the command of feeding the hungry as confirmed in the story of Jesus feeding the multitude. The gospel authors considered this as essential to be recorded in their books (Webster 2013:366-67). Although each author employed the story for a different context and purpose, all four consistently recorded that the hungry should be fed (Mt 14:16, 20; Mk 6:37, 42; Lk 9:13, 17; and Jn 6:5, 13).

The TCF includes farmers in church ministry as subjects in the transformative diakonia by respecting them and valuing their work. It challenges a view that only considers the elders or deacons or pastors as servants/ministers of God. Instead, the TCF affirms that the farmers are also doing a great ministry by providing food for all people as Jesus commands. From their work, Jesus' disciples finally distributed the loaves. This is an example of the way that food must be provided for the table service of Christian churches. Accordingly, the farmers' existence and work illuminate a mark of ecclesial life that is "service to others," as asserted by Daniel Migliore (2014:263). Not only do the farmers serve others with food, but they are also served by the others in appropriate ways to overcome the challenges in their mission against hunger.

When the story of the farmers in GMIT's context and the story of Jesus feeding the multitude are juxtaposed, it is appropriate to imaginatively say that the peasants are welcomed and involved in Jesus' ministry by providing loaves. Their existence is respected, and Jesus needs the food they produce. However,

3 I was a team member of the Theological Development Unit of GMIT from 2017 to 2018. In an event of ministry we organized in 2018 , Kompastani was invited to present their creative form of ministry. 
did not Jesus also feed the 4000 and 5000 people with fishes? Who provides the fishes? These questions point to what is neglected in the TCF.

While on the one hand the TCF positively affects farmers' life in GMIT and other churches that might have similar ecclesial issues, on the other hand the TCF actually has the opposite effect for fishers who are also part of the congregations, especially in coastal areas. The abandonment of fish and fisher as depicted in the previous section has a negative consequence for ecclesial life. Unlike the farmers who are advocated for by the WCC through the TCF formulation, the WCC has nothing to say about the exploitation of the fishers although the TCF guidelines recognize that exploitation. The TCF acknowledges the marginalization experienced by artisanal fisher folk, but the TCF itself also marginalizes the fishers from ecclesial life by the contents of its commandments.

The food the fishers eat and offer to other people is not recognized in the TCF even though fish is acknowledged as a big source of animal protein in the guideline (WCC 2016:20). As recently reported by Food and Agriculture Organization, about 17 percent of animal protein of the global population comes from fish (FAO 2018:2). Some 59.6 million people depend on the sea for their livelihood, with 40.3 million people engaged in capture fisheries and 19.3 in aquaculture (FAO 2018:30). Located in the eastern part of Indonesia, which is the largest archipelagic state in the world (Morris and Paoli 2018:15), GMIT has many congregations situated in coastal areas. Members of those congregations eat fish as the main source of their protein. Some of them work as farmers (in agriculture and aquaculture) in one season and fishers in another season. Others work only as fishers, taking food from the sea either by nets, fishing lines or other traditional techniques. Facing danger at sea, the fishers work hard for themselves and for other people who need fish, even though many of them are poor and vulnerable fishers who can do nothing against fishery market mafia and their exploitation.

As fishers, these people can give no loaves but only fish to Jesus. From their income as fishers, they bring offerings to their congregations for the diverse forms of ministry. They train and improve themselves with appropriate skills and knowledge, and risk themselves to provide nutritious food for many people. Through their work, Jesus' disciples finally can share the two fishes, and seafood is provided for the table service of Christian churches. Unfortunately, the TCF does not take these all into account. Unlike the farmers, the fishers are not considered as subjects of the church ministry of transformative diakonia. Jesus did include the fishers in his ministry of feeding the hungry, yet the TCF excludes and marginalizes them. That exclusion is, admittedly, contradictive to the new mission affirmation of the wCc itself, "Together towards Life - Mission 
and Evangelism in Changing Landscapes," in which mission from the margins is fundamental (ed. Keum 2013:15-6). Hence, although it might be unintentional, the TCF fails to include the fishers in the fellowship and mission of the Christian church which supposes to embody the work of Jesus Christ, the head of the Christian church.

\section{The Implications of the TCF for the Environmental Crisis}

The TCF affirms the significance of nature and challenges destructive practices toward nature. As it speaks of a basic need of human beings, that of food, and addresses the medium where food is from, the TCF has a huge significance for the conservation or restoration of degraded environments. By focusing on how food is grown, farmers are supported. The environment becomes more likely to be protected from pollution and exploitation. With this campaign, Christian churches play an important role in raising another voice ${ }^{4}$ to deal with food security issues by valuing the nature that generously gives food, and proclaiming it as a matter of faith. In so doing, it supports and strengthens other voices from different religious, institutional and professional backgrounds that have the same concern (See McLeod and Palmer 2015:239). Interestingly, the TCF also includes practices it commands be done. It is a voice spoken through actions as previously displayed in the works of Kompastani and the farmers of GMIT. The TCF is a campaign in word and deed.

That kind of campaign makes the TCF effective for environmental care. Based on their research findings on how religion can encourage its adherents to act for environmental care, Vaidyanathan et al. (2018:473) claim that "religious institutions can motivate members' environmental actions when they cultivate not only declarative environmental beliefs but also non-declarative environmental practices." Accordingly, only if a statement of faith declared in order to encourage the care of nature, for instance, is followed by opportunities created for the adherents to practice it, will that religion achieve a good result. It is, therefore, not only about awareness that exercising care for nature is a matter of faith but also to know how to or in what ways a person can practically embody it (Vaidyanathan et. al. 2018:475-6). With this characteristic of the campaign - in word and deed - the TCF meets this requirement because it contains both a declaration of faith and an opportunity to embody that

4 According to Sigurd Bergmann (2009:104), various voices and diverse perspectives are necessary in addressing climate change issues. I believe that Bergmann's view also applies to the issue of food security. 
declaration. In doing the TCF, a congregation affirms the importance of caring for nature and at the same time practices it. For the farmers, especially, preserving nature here is not a new program, but it is their daily life. Also, the TCF places the locals with all their capacity - local knowledge and experiences in relation to their environment - as the subject for environmental care in a spiritual framework. Accordingly, it is plausible to say that the TCF makes people, to use Michael Northcott's words, "recover a sense of the spiritual significance of treasuring and guarding their own local ecosystems" (2007:15).

In the GMIT context, furthermore, the TCF exceeds the criteria suggested by Vaidyanathan et al. The TCF has more than just a belief and practice of caring for nature. For the farmers, respecting and preserving the environment is a celebration of themselves being included in the ministry of their faith community. This absolutely makes the farmers more enthusiastic. They consider this opportunity as an essential part of their faith experience. For the non-farmer members, meanwhile, doing the TCF is also a sign of accepting and respecting their brothers and sisters who work as farmers in their community of faith. It is both a mission of caring for the environment, but also a celebration of farmers being included in God's work.

In addition, the TCF has the capacity to involve many people to respect and cultivate nature in the best ways. This campaign is directed to the fellowship of Christians whose profession may or may not have a connection to the protection of the environment. The TCF creates space ${ }^{5}$ for the experts (environmental scientists) and the non-experts (local farmers) to collaboratively engage in cultivating and conserving the environment. Certainly, this does not mean that the collaboration will run well due to, for instance, the different knowledge and ways of caring for nature which create tensions between the two scientists with their universal/placeless approach and local farmers with their local/place-based approach, as Roy Rappaport (1999:456-9) asserts. Christian churches, in fact, have the capacity to solve this split. The work of Kompastani is an example. The point here is that the TCF creates space for people from different background of expertice and experience to work together in caring for the environment.

Nevertheless, the significance of the TCF for the environment is only applied positively to the land, while the sea which is a source of life and vulnerable to destructive practices of humans does not benefit from that campaign. This fact has enermous negative impacts on the sea and the whole life on this planet because the sea is very decisive for that life. Sylvia Earle (2016:156) claims that

5 This kind of space is essential as Northcott demonstrates in his work on the conservation of the endangered leatherback turtle in West Malaysia (2012). 
the ocean is "the cornerstone of our planet's life support system and the cornerstone of the ocean's life support system is life in the ocean." The sea provides water, food and oxygen. For water, the ocean has a massive contribution to bringing water through the rain to the forest and land, for soil and farming areas so that the farmers can cultivate their land. For food, the sea provides millions of tons of fish every year. For oxygen, the phytoplankton in the sea produces oxygen to sustain life on earth. Hence, Earle is correct to assert that to care for the ocean is to preserve the life of this blue planet (2016:158).

In that regard, it is not reasonable to talk and work for food security without securing the sea. The protection of the sea is essential because the sea is vulnerable as confirmed by diverse problems concerning the sea today (Srokosz and Watson 2017:184-85). Plastic pollution, oil contamination, over-fishing or exploitation, illegal and destructive fishing, have negative impacts on the marine ecosystem. Climate change is threatening the life in the sea and the whole earth. Unfortunately, the TCF left the sea overlooked. There is not any command to protect the sea, whereas the participation of Christianity in this issue is necessary.

Instead of encouraging Christians to protect the sea, the TCF falls on preserving the negative views of the sea in Christianity which endanger the sea. In Indonesia, for instance, a negative view of the sea is found in a Christian pop song and a Sunday school song which are popular among Indonesian Christians. The pop song titled Sejauh Timur dari Barat (As Far as East is from West) speaks of God's forgiveness. Being resonant with Micah 7:17, it says in its lyric Jauh ke dalam tubir laut Kau melemparkan dosaku (Into the depth of sea you cast my sin). The title of the Sunday school song is Aku Bahagia (I am happy) as a joyful expression of people whose burden is taken by Jesus. Its lyric says Aku bahagia karena Tuhan Yesus angkat bebanku. Yesus angkat bebanku dan buang ke laut, buang ke laut, buang ke laut (I am happy because Jesus takes my burden/sin and casts it into the sea, casts it into the sea, casts it into the sea). From their childhood, Indonesian Christians have known that the sea is the place of sin or bad things. This negative view is preserved by disasters that occurred in many regions of Indonesia due to human failure in responding to the tsunami, which is a natural phenomenon. Some Christians in Indonesia might not have read or memorized Micah 7:19, yet they know and their thought-world is arguably shaped by that view from the songs. ${ }^{6}$ That view

6 Based on the work of Steven Mithen, The Singing Neanderthals: The Origins of Music, Language, Mind and Body, Edmund Newell suggests that Christian hymns/songs can shape Christians' thinking. Their theological views can be generated, as a heritage of faith, from familiar words and phrases they sing from generation to generation (2019:103-4). 
might not directly make Christians throw their waste including plastic material into the sea. However, that view gives the idea of waste dumping into the sea (Cf. Patton 2007:13, 24). As a result, many Christians throw away plastic waste and take the sea for granted (Cf. Keller 2000:185). In Indonesia where waste management is poor, plastic pollution in the sea is inavoidable. ${ }^{7}$ With its simple formulations like those songs, the TCF could effectively challenge this idea and, at the same time, raise Christians' awareness of the significance of the sea. Yet, the neglect of the sea in the campaign makes that idea unchallenged, and the sea remains less-concerned. Consequently, the literalization of "the apocalyptic tehomicide," to use Catherine Keller's words (2000:185), is inevitable.

\section{Fish, Fisher, and Sea Included: A Christian Mission in the Marine} Ecological Crisis

I have demonstrated the TCF as an innovative and effective campaign of the Christian church for food security, but it only applies to the food that farmers can provide from the land. It is effective but non-comprehensive. Its incompleteness negatively affects ecclesial life and marine life. Therefore, it is essential for the TCF to include fish (seafood), fishers and sea in the TCF wherever it is appropriate. The inclusion of these three words in the TCF will give more weight to the innovativeness and the effectiveness of the campaign as a mission for just and sustainable life and an ecclesial way of life in the midst of marine ecological crisis.

In this context, the TCF encourages the securing of important nutritious food for the world. It is by embodying the command of God to "... have dominion over the fish of the sea ..." (Gn 1:26, 28) in the frame of the community of creation in which every creature has an intrinsic value, live in respect one another and celebrate their interdependence (Bauckham 2016:19, 64-102; Johnson 2014:268). In this framework, human and the sea and its creatures participate in God's order of creation, working cooperatively for the flourishing life of this planet (Cf. Bauckham 2016:19; Atkinson 2019:10). Such encouragement is crucial because of the ubiquitous over-fishing and exploitative practices that harm the sustainability of sea creatures. With fish in the TCF, thus, Christian churches challenge those practices. They resist injustice at sea and monopoly of sea resources embodied, for instance, in any practice which

7 Indonesia is the second-largest contributor in the world of plastic pollution in the sea (Jambeck et al. 2015:769). 
places the fish as food for the wealthy people only or what Conradie (2018:77) means by hedonistic consumption. Through this mission, the churches also let the sea creatures as part of God's creation be themselves and joyfully play their roles God has given (Bauckham 2011:184). In this case, one of their contributions is to offer enough nutritious seafood for the multitude, especially the hungry and the needy.

The inclusion of fisher in the mission of the Christian church is a clear affirmation of the role and right of fishers. Fishers can also be part of God's work in Christian mission as well as farmers. Through that role, Christian churches can make sure that all people, not only the wealthy ones, have enough nutritious food. For their welfare, the Christian church raises a prophetic voice for their right to be fulfilled and themselves to be protected from exploitation.

This inclusion, in fact, echoes Jesus' resistance to the exploitative practices experienced by Galilean fishers through his call of the first four disciples, the fishers. As claims F. Scott Spencer (2005:143-46), "follow me" in that narrative in the synoptic gospels is an imperious call (for the Kingdom of God) that resists the exploitative and corruptive fishing industrial system of the Roman-Galilean Empire in Galilee. It is clear that the Galilean fishers did not fish at sea (saltwater) but lake (freshwater). Consequently, it seems not quite appropriate to use their story in this discussion. However, in addition to the high hills surround the lake which create natural phenomena (winds, waves and storm) similar to what happens to the sea (Newell 2019:26), the Galilean fishers were in the same pattern of exploitative fishing industry system at the ancient Mediterranean Sea. The fishing industry at the lake of Galilee was under the exploitative control/regulation (taxes, etc.) of Herod Antipas (the tetrarch of Galilee), a Roman Empire client-king (Hanson 1999:10o; Hakola 2017:124-6; Myles and Kok 2019:377-84). One of his tasks as a client-king was to collect taxes and then pay tribute to the Roman Empire, which had esablished systems of tribute throughout the Mediterranean region (Hanson 1999:10o-o3; Spencer 2005:145; Carter 2008:130-31; Kloppenborg 2018:595-6).

The monopoly of the Roman Empire is, in my view, a fundamental reason for the authors of the gospels of Matthew, Mark and John - and only them (Newell 2019:25-6) - to count the lake as sea, certainly with a particular theological motif. The authorship of the three gospels have been associated with the tax collector (Matthew) and the fishermen (Mark and John) who directly experienced how exploitative the Roman system was (Myles and Kock 2019:38o-84). They knew that such a system had created injustice and a huge economic gap between the ruling elites and the conquered ordinary people in the whole Empire. John, for instance, with his background as a fisherman challenged it in the book of Revelation (Bauckham 1993:35-9; Koester 2009: 5, 9-12). This 
confirms that he has expanded the reach of Jesus' resistance. Accordingly, the use of sea (thalassa) rather than lake (limne) in the three gospels can be seen as a way to insist Jesus' lordship over the sea with all its evil power depicted in the monopoly of the Roman Empire at the inland water of Galilee and Mediterranean Sea. This is their particular motif, a resistance by demonstrating how the lordship over the sea should be embodied, with the lake of Galilee as the archetype of the Mediterranean Sea. Thus, referring to Jesus' works in relation to the lake of Galilee as recorded especially in the three gospels to address theologically the exploitation of the fishers is sound.

The call of the four fishermen to join Jesus' resistance is a way Jesus worked through the disciples to resist the exploitative practices at sea on a wider scope of the Roman Empire that had obstructed the participation of the fishers in God's provisional work for all people. In that movement, Jesus taught the disciples how the true lordship over the sea is embodied economically through the feeding of the multitude with fresh fish that were usually consumed only by the wealthy (Batten 2017:5-12). Raj Nadella (2016:172-4) asserts that through the feeding, Jesus challenged the centripetal movement of resources for the interests of the ruling elites. In contrast, Jesus performed a centrifugal movement of resources. The feeding positions the Galilean villagers, the multitude, as the recipients of essential commodities in and through that event. Accordingly, the work of the Galilean fishers should benefit all people including themselves as they do not work for the Roman Empire, but the Kingdom of God.

The author of Mark continues this theme of Jesus' resistance against the Roman economic structure by placing this story (Mk 6:30-44) next to Herod's banquet (Mk 6:14-29). This juxtaposition demonstrates the contradiction of economic system between the elite and the multitudes (Nadella 2016:173). With that, Mark resists the exploitative system of the Roman Empire by demonstrating the system of the Kingdom of God performed by Jesus in the feeding narrative.

In a different context, John also continues that resistance throughout the book of Revelation in which he demonstrates the fall of the exploitative/ demonic economic and political system of the Roman Empire. He announced the end of the caesar's lordship over the sea embodied in his economic and political practices which made the sea as a means and source of suffering and death for the conquered people (Middleton 2014:169; Koester 2009:14-18). The former fisherman proclaims: the sea was no more, death will be no more in the renewed heaven and earth, as seen in Revelation 21:1, 4 (Aune 1998:1114). It is not the salt water body, but the Romans' exploitative order which transformed the sea into a means of evil which will be annihilated (Cf. Beasley-Murray 
1994:1452). John insists that the sea will be liberated from the imperial Roman's exploitation which had denied the contribution of fishers to making the life of all people, the poor and the marginalized including themselves, flourish.

The call of the four fishermen, nevertheless, cannot be read in a way that encourages everyone to be a fisher of people in order to stand against that exploitation. In fact, there were only four fishers called to do that on this occasion, while the other fishers of Galilee in particular partake in Jesus' resistance by providing fish for the feeding of the multitude, so to speak. The four fishermen were called to raise prophetic voices resisting the monopoly, and to make their fellow fishers able participate in Jesus ministry by providing fish, nutritious food, for all people. The fishers do not work to enrich a small group of people with political and economic power, but to make their and all others' life flourish with food from the sea.

Hence, the inclusion of fishers in the TCF resonates with Jesus' resistance to the exploitative system which oppressed and denied the participation of fishers in God's holistic mission. With that inclusion, Christian churches like the four fishers proclaim God's work for and through fishers that in turn make all people have enough nutritious food. In terms of God's work for the fishers, the inclusion will make the TCF a prophetic voice through which the churches advocate for fishers and challenge all that obstruct their participation in God's holistic mission. The TCF does not only recognized the exploitation experienced by fishers (WCC 2016:15-16), but also explicitly resist systems and practices which exploit fishers in any form. In regards to God's work through fishers, the TCF acknowledges their participation in God's mission and empowers them to proclaim to the world Jesus' lordship over the sea. They are, to use the words of David Bosch (1995:34), "alerting people to the universal reign of God" at the sea. From their works, all people could experience a form of God's provision: all, especially the poor and the marginalized, eat and are filled (Cf. Mk 6:42). These all will make the TCF become a record of fishers alongside farmers partaking in God's ongoing work of feeding the multitude embodied in the transformative diakonia ministry of Christian churches today, just like the gospels recorded the Galilean fishers' participation in Jesus' ministry of feeding the hungry with the two fishes alongside the five loaves.

With equal attention to the sea, the TCF will play a key role in encouraging Christians to care for and restore the sea as a form of church mission. The negative view of the sea in Christianity discussed in the previous section will be challenged. The destructive acts generated by that negative view will be replaced with the constructive ones which lead to the preservation and protection of the sea. For the sea is part of God's creation that brings life to all 
living creatures in this blue planet. As Winston Halapua (2008:93-5) beautifully says, the sea unceasingly speaks of God's love that gives life through the waves breaking over reefs and embracing the coastlines.

The TCF will also encourage the readings of the biblical accounts of the sea with proper interpretation and theological reflection in the context of the marine ecological crisis today. A unique work of Meric Srokosz and Rebecca S. Watson, and the recent work of Newell are crucial attempts to reinterpret the biblical narratives and reflect on theological perspectives of the sea in the context of marine crisis. Their works affirm that Christianity must challenge views and activities that harm the sea and its creatures, and encourages the faithful to be sea-friendly. Srokosz and Watson (2017:229-34), after dealing with major biblical accounts on the sea, suggest that if we truly believe that the existence of the sea - its dynamics and roles for the whole creation - comes from God, then we should live as the blue people who have "concern for the welfare of the sea and its creatures, for our fellow human beings, and for the planet as a whole." That concern should be embodied in manifold actions as our response to God's concern for the whole creation in the context of our current environmental crisis. Doing nothing is the same as destroying God's good creation (Srokosz and Watson 2017:231). Newell, who explores the spiritual pieces of the sea through Christian history, shows that our relationship with the sea is, even, beyond consumptive matter. He claims that the sea is highly sacramental in the sense that through it we are bestowed with particular knowledge and experience of God (2019:140-41). Our spirituality springing from that encounter is signified by the way we treat the sea: with no violation and destruction but reverence and respect (Newell 2019:144-5).

The works of Srokosz and Watson, and Newell are undoubtedly helpful, and the TCF can be an adequate articulation of those works for Christians, especially the grassroots, in addressing the food security issue. As stated in the introduction, the TCF is a significant campaign for food security. It is easier for the TCF to reach the grassroots in congregational contexts. With this advantage, the TCF can be the most effective way to transmit the works of Christian scholars concerning the sea. As a result, the inclusion of the sea will make TCF a more significant and effective instrument to challenge the negative view and attitudes toward the sea. Not injustice and death, but life for all coming from the sea like the restless waves the TCF resonates. At the same time, the TCF invites and encourages Christians - fisher and non-fisher, coastal people and highlanders - to be sea-friendly so that the sea keeps becoming a place for nutritious food for all people, as one of its contributions for life in this blue planet. 
The inclusion of fish, fisher, and sea will make the TCF an innovative model of Jesus' ministry of feeding the multitude in the context of the marine ecological crisis today. How the sea feeds those considered as the needy in many coastal communities in GMIT's context could be a case in point. For these communities, the seafood (aquatic plants and animals) which can be collected/ caught directly from the sea during the low tide is intentionally intended for those who cannot afford a boat and more adequate fishing equipment to fish (Therik 1997:76-8). The society of Pantai Rote in Semau Island uses two local expressions (often found in traditional poetry) that point to this group of people. They are ina falu (widows) and ana mak (orphans) whose food is dependent on the sea (Therik 1997:77). With traditional and simple equipment, ina falu and an a mak collect/catch their food directly from the sea during the low tide twice a day (Therik 1997:76). The condition of the marine ecosystem in the shallow sea is decisive for this practice. If the ecosystem is damaged by plastic pollution for instance, it will affect the availability of the seafood for these people.

In the context of the marine ecological crisis today, with fish, fisher and sea included the TCF becomes a campaign of Christian churches for the food security of the ina falu and ana mak. In continuity with the five loaves and two fishes, the Christian churches echo Jesus' work of feeding the multitude by being sea-friendly, respecting and preserving the sea as well as assuring that the ina falu and ana mak continue to have access to the sea's resources. In so doing, the sea-friendly TCF will be a novel way for Christian churches to support the sea to feed the hungry and the poor as one of its contributions for life.

\section{Conclusion}

With fish, fisher, and sea included, the TCF fully becomes an innovative and effective campaign for food security with a substantial positive impact on ecclesial life and environment. It becomes a mission conducted collaboratively by all believers for the sustainability of the common oikos, the dwelling place of all living creatures (Andrianos 2018:602-4). As farmers care for the land, so do fishers care for the sea as a celebration of their inclusion in the holistic mission of the Christian church. In the context of marine life crisis and all efforts to face the crisis, the participation of the fisher is vital. The sea and land with all their potentials and contributions to life must be respected as an ecclesial way of life. In this regard, the TCF becomes an essential contribution of Christian churches for the world. In diverse ways, it can 
encourage and mobilize all Christians in coastal areas and inlands working hand in hand as a fellowship in a shared mission to secure food, respect and protect food workers, and preserve all places/mediums that give food. The ina falu and ana mak as well as the marine life, in particular, will benefit from this mission.

\section{Acknowledgements}

I am grateful to Peter Manley Scott, my supervisor, whose insights are influential for me in writing this article, Steve Taylor, John Campbell-Nelson and Caleb Gordon for their helpful comments and language corrections on drafts of this work.

\section{Funding}

This work is funded by the Indonesia Endowment Fund for Education (LPDP).

\section{References Cited}

Andrianos, Louk A. (2018). "Ecumenical Theology of Hope for the Common Oikos and the Greed Line as Principle of Sustainability." The Ecumenical Review 70 (4): 6oo616. DoI: 10.1111/erev.12387.

Atkinson, David (2019). "Christian Ethics and Climate Change." Crucible: The Journal of Christian Social Ethics, April: 5-13.

Aune, David Edward (1998). Revelation 17-22. Nashville, Tenn: Thomas Nelson.

Batten, Alicia J. (2017). "Fish Tales." Biblical Theology Bulletin 47 (1): 5-14. Dor: 10.1177/ O146107916682196.

Bauckham, Richard (1993). The Theology of the Book of Revelation. Cambridge: Cambridge Press.

Bauckham, Richard (2010). Bible and Ecology: Rediscovering the Community of Creation. London: Darton, Longman and Todd.

Bauckham, Richard (2011). Living with Other Creatures. Texas: Baylor University Press. Beasley-Murray, George R. (1994). "Revelation." In D. A. Carson, ed. New Bible Commentary, 21st Century Edition. Illinois: Inter-Varsity Press: 1421-1455. 
Bergmann, Sigurd (2009). "Climate Change Changes Religion: Space, Spirit, Ritual, Technology-Through a Theological Lens." Studia Theologica 63 (2): 98-118. DoI: 10.1080/00393380903345057.

Bosch, David J. (1995). Believing in the Future: Toward a Missiology of Western Culture. Valley Forge: Trinity Press.

Burke, Lauretta, Kathleen Reytar, Mark Spalding and Allison Perry (2013). "Reefs at Risk Revisited in the Coral Triangle." World Resources Institute.

Carter, Warren (2008). "Matthew Negotiates the Roman Empire." In Richard A. Horsley, ed. In the Shadows of Empire. Louisville: Westminster John Knox: 117-136.

Conradie, Ernst M. (2018). “To Eat or Be Eaten? That's the Question.” In Laura Hobgood and Whitney Bauman, eds. The Bloomsbury Handbook of Religion and Nature: the Elements. London: Bloomsbury Academic: 63-78.

Dzwonkowska, Dominika (2018). "Is Environmental Virtue Ethics Anthropocentric?" Journal of Agricultural and Environmental Ethics 31 (6): 723-738. DOI: 10.1007/ s1o8o6-018-9751-6.

Earle, Sylvia (2016). "Protect the Ocean, Protect Ourselves." In Marcha Johnson and Amanda Bayley, eds. Coastal Change, Ocean Conservation and Resilient Communities. Cham: Springer International Publishing: $155^{-160 .}$

FAO (2018). The State of World Fisheries and Aquaculture 2018 - Meeting the Sustainable Development Goals. Rome. Licence: CC BY-NC-SA 3.o IGO.

Fitriana, Ria and Natasha Stacey (2012). "The Role of Women in the Fishery Sector of Pantar Island, Indonesia." Asian Fisheries Science Special Issue 25: 159-175.

Hakola, Raimo (2017). "The Production and Trade of Fish as Source of Economic Growth in the First Century CE Galilee: Galilean Economy Reexamined." Novum Testamentum 59 (2): 111-130. DOI: 10.1163/15685365-12341561.

Halapua, Winston (2008). Waves of God's Embrace: Sacred Perspectives from the Ocean. London: Canterbury Press.

Hanson, K. C. (1999). "The Galilean Fishing Economy and the Jesus Tradition." Biblical Theology Bulletin 27 (3): 99-111. DoI: 10.1177/o14610799702700304.

Jambeck, Jenna R., Roland Geyer, Chris Wilcox, Theodore R. Siegler, Miriam Perryman, Anthony Andrady, Ramani Narayan and Kara Lavender Law (2015). "Plastic Waste Inputs from Land into the Ocean." Science 347 (6223): 768-771. https://doi .org/10.1126/science.126o352.

Johnson, Elizabeth A. (2014). Ask the Beasts: Darwin and the God of Love. London: Bloomsbury Academic.

Keller, Catherine (2000). "No More Sea: the Lost Chaos of the Eschaton." In Dieter T. Hessel and Rosemary Radford Ruether, eds. Christianity and Ecology: 
Seeking the Well-being of Earth and Humans. Cambridge, Massachusetts: Harvard University Press: $183^{-198 .}$

Keum, Jooseop, ed. (2013). Together towards Life: Mission and Evangelism in Changing Landscape-With a Practical Guide. Geneve:World Council of Churches Publications. Kloppenborg, John S. (2018). "Jesus, Fishermen and Tax Collectors: Papyrology and Construction of the Ancient Economy of Roman Palestine." Ephemerides Theologicae Lovanienses 94 (4): 571-599. DoI:10.2143/ETL.94.4.0000000.

Koester, Craig R. (2009). "Revelation's Visionary Challenge to Ordinary Empire." Interpretation 63 (1): 5-18. DoI: 10.1177/oo2096430906300102.

Mcleod, Elizabeth and Martin Palmer (2015). "Why Conservation Needs Religion." Coastal Management 43 (3): 238-252. DOI: 10.1080/08920753.2015.1030297.

Middleton, J. Richard (2014). A New Heaven and A New Earth: Reclaiming Biblical Eschatology. Grand Rapids: Baker Academic.

Migliore, Daniel L. (2014). Faith Seeking Understanding. Grand Rapids: Wm. B. Eerdmans Publishing Co.

Morris, Lyle J. and Giacomo Persi Paoli (2018). A Preliminary Assessment of Indonesia's Maritime Security Threats and Capabilities. Cambridge: RAND.

Myles, Robert J. and Michael Kok (2019). "On the Implausibility of Identifying the Disciple in John 18: 15-16 as a Galilean Fisherman." Novum Testamentum 61 (4): $3^{6} 7^{-}$ 385. DOI: $10.1163 / 15685365-12341637$.

Nadella, Raj (2016). "The Two Banquets: Mark's Vision of Anti-Imperial Economics." Interpretation 70 (2): 172-183. DOI: 10.1177/oo20964315622998.

Newell, Edmund (2019). The Sacramental Sea: A Spiritual Voyage through Christian History. London: Darton, Longman and Todd.

Niyonsaba, Françoise (2018). "Mission Is Not Only About Preaching." International Review of Mission 107 (2): 458-471. DOI: 10.1111/irom.12243.

Northcott, Michael S. (2007). A Moral Climate: The Ethics of Global Warming. London: Darton, Longman and Todd.

Northcott, Michael S. (2012). "Buddhist Rituals, Mosque Sermons, and Marine Turtles: Religion, Ecology, and the Conservation of a Dinosaur in West Malaysia." Journal for the Study of Religion, Nature \& Culture 6 (2): 196-214. DOI: 10.1558/jsrnc.v6i2.196.

Patton, Kimberley C. (2007). The Sea Can Wash Away All Evils: Modern Marine Pollution and the Ancient Cathartic Ocean. New York: Columbia University Press.

Rappaport, Roy A. (1999). Ritual and Religion in the Making of Humanity. Cambridge: Cambridge University Press.

Spencer, F. Scott (2005). "'Follow Me' The Imperious Call of Jesus in the Synoptic Gospels." Interpretation 59 (2): 142-153. DOI: 10.1177/oO2096430505900204.

Srokosz, Meric and Rebecca S. Watson (2017). Blue Planet, Blue God: The Bible and the Sea. London: SCM Press. 
Therik, Tom (1997). "Meramu Makanan dari Laut: Kearifan Masyarakat Pantai Rote di Semau" [Collecting Seafood from the Sea: Local Wisdom of Pantai Rote Society in Semau]. Setia 1:76-91.

Vaidyanathan, Brandon, Simranjit Khalsa and Elaine Howard Ecklund (2018). "Naturally Ambivalent: Religion's Role in Shaping Environmental Action." Sociology of Religion 79 (4): 472-494. DOI: 10.1093/socrel/srxo43.

Webster, Jane S. (2013). "That One Might Not Fall: A New Testament Theology of Food." Interpretation: A Journal of Bible and Theology 67 (4): 363-373. Dor: 10.1177/0020964313495520.

White, Alan T., Porfirio M. Aliño, Annick Cros, Nurulhuda Ahmad Fatan, Alison L. Green, Shwu Jiau Teoh, Lynette Laroya, Nate Peterson, Stanley Tan, Stacey Tighe, Rubén Venegas-Li, Anne Walton and Wen Wen (2014). "Marine Protected Areas in the Coral Triangle: Progress, Issues, and Options." Coastal Management 42 (2): 87-106. DOI: 10.108 o/o8920753.2014.878177.

World Council of Churches/wcc (2016). Ten Commandments of Food-Advocacy Tools for Congregations. Geneve: World Council of Churches Publications.

World Council of Churches/wcc n.d. "Protestant Evangelical Church in Timor." World Council of Churches. Accessed August 18, 2020. https:/www.oikoumene.org/en/ member-churches/protestant-evangelical-church-in-timor.

\section{Resumen}

Este artículo ofrece una respuesta teológica a los Diez mandamientos de los alimentos (TCF por sus siglas en inglés) en el contexto de la crisis ecológica marina. El TCF es una campaña única y eficaz que promueve una vida sustentable a favor de la seguridad alimenticia mediante la misión de las iglesias cristianas. La campaña incluye a los agricultores y replantea la seguridad alimentaria y la sustentabilidad como parte de la vida eclesial. Pero el descuido de los peces, los pescadores y el mar por parte del TCF tiene consecuencias negativas para el ecosistema marino. Esta exclusión pone en peligro la sustentabilidad de la vida marina y de todos aquellos que dependen del mar como sustento y medio de vida. Por lo tanto, este artículo sugiere que es esencial incluir peces, pescadores, y el mar en el TCF - observa que tienen un lugar fundamental en el cristianismo particularmente en cómo están representados en el ministerio de Jesús y sus discípulos. Esto hará que el TCF sea una campaña más completa con contribuciones positivas para la vida marina. 


\section{摘要}

这篇文章在海洋生态危机的背景下对食物十诫 (TCF) 做出了神学回应。TCF 是一项 独特而有效的食物安全运动, 倡导通过基督教会的使命实现可持续的生活。由于 该运动包括农民, 它将食物安全和可持续性重新定义为教会生活的一部分。然而, TCF 中对鱼类、渔民和海洋的忽视会对海洋生态系统产生负面影响。这种排斥危及 海洋生物的可持续性以及所有依赖海洋谋生的人。因此, 本文建议将鱼类、渔民和 海洋包括在 TCF 中是必不可少的一并指出它们在基督教中占有重要地位, 特别是在 耶稣及其门徒的事工中所描绘的那样。这将使 TCF 成为一项更全面的运动, 为海 洋生物做出积极贡献。 